\title{
The effectiveness of using Metallocene fertilizers for the spray- dressing of winter wheat
}

\author{
Ilshat Vafin and Radik Safin* \\ Kazan State Agrarian University, Department of General Agriculture, Plant Protection and Section, Kazan, 420011, Russia
}

\begin{abstract}
This article presents the impact assessment results for the spay-dressing of different Metallocene compound fertilizers containing chelated microelements on the yield and quality of winter wheat seeds of the Kazanskaya 560 variety. The research was carried out on the grey forest soils in the Kama region of the Republic of Tatarstan in 2017-2020. The plants were dressed with fertilizers in the autumn and the spring and summer period. In the autumn, we used the fertilizer containing manganese (Metallocene D), and in the spring and summer period (the tillering and earing stages of the winter wheat), we used the Metallocene Universal compound fertilizer with several microelements. During the research, we established that applying the manganese-containing Metallocene D in the autumn has a significant positive effect on the growth and dry biomass accumulation of the winter wheat. The dressing with Metallocene Universal during the tillering and earing stages following the application of Metallocene D in the autumn resulted in an increased/stimulated plant growth and development. The highest yield of winter wheat (3.45 t/ha or $46 \%$ above the reference value) was obtained through the dressing of Metallocene D at a rate of $21 /$ ha in the autumn, and the spraying of the plants with Metallocene Universal done twice during the spring and summer period. The autumn application of Metallocene D and the twofold application of Metallocene Universal improve the qualitative parameters of new winter wheat seeds. The use of fertilizers in questions improved the laboratory germination of the seeds and significantly reduced the root rot agent infection rate. The twofold dressing during the spring and summer period following the autumn dressing helped to suppress the most dangerous infections, such as the fusarium blight and the Helmintosporium disease, in the new seeds almost completely. The research conducted showed that Metallocene fertilizers can be successfully used to improve the production of winter wheat and seeds.
\end{abstract}

\section{Introduction}

One of the key global problems of sustainable production of grain crops to cover the needs of the growing population of the planet is quality seed production [1]. Seed production stipulates the development of specialized agrotechnologies adjusted to fit the growing conditions of a specific area and the agrobiological requirements of the crops, including those concerning global climate change [2-4]. Due to this, developing techniques to improve the quality of seeds and their yield is a relevant academic problem.

Winter wheat is one of the key grain crops for the Russian Federation and the Republic of Tatarstan as it has great potential for yield increase and grain production for exports [5-7]. That being said, the survival of plants over winters is especially important for crop output in the continental climate of Russia [8].

One of the methods to improve the output of winter wheat is the optimization of mineral nutrition and application of various fertilizers in the autumn [9]. Besides, the biological features of the crop condition the plant requirements for other macro and microelements at all stages of their organogenesis [10]. It is known that macro and microelements have a significant impact on the growth and development of crops. Microelements like manganese, zinc, and boron play a significant part in carbohydrate and protein metabolism. Copper is a component of many enzymes, including cytochrome oxidase, polyphenol oxidase, etc. Boron impacts plants' water intake, facilitates their blooming and ripening while also increasing the amounts of flowers and fruits, yield output, and quality $[11,12]$.

Due to this, it is especially important to have scientifically justified fertilization procedures for winter wheat [13]. The foliage application (spraying) of nutrients has become increasingly popular [14]. This method often relies on liquid compound fertilizers containing macro and microelements [15-17] including, among others, the Metallocene solutions (produced by Biokhimservis LLC in Kazan). The key advantage of the liquid fertilizers used for plant spraying is the flexibility of their application during various plant development phases taking into account their needs.

The quality of seeds is another key problem of winter wheat production. The mineral nutrition of plants is especially important for the improvement of both the sowing and yield parameters of seeds. We know that

\footnotetext{
Corresponding author: radiksaf2@mail.ru
} 
microelements have a positive effect on the seed in the next harvest [19]. Some of the researchers claim that microelements can improve the resilience of plants against diseases [20, 21]. Apart from that fertilizer spraying has a positive impact on the reduction of plant disease rates $[22,23]$.

Thus, it is necessary to study the efficiency of Metallocene fertilizer range in foliage spraying of winter wheat when grown for seed production.

\section{Materials and Methods}

The subject matter of the research is a local winter wheat variety known as Kazanskaya 560. The research was carried out over three vegetation periods (2017-2018, 2018-2019, and 2019-2020) on the experimental fields of Kazan State Agrarian University. The weather during the vegetation period in the research years featured regular droughts but otherwise were relatively good for harvesting winter wheat. The 2019-2020 season was especially good for winter wheat.

For the research purposes, we performed experiments as follows: 1. Reference - no dressing; 2. Metallocene D (1.0 1/ha) with manganese (autumn dressing). 3. Metallocene D (2 1/ha) with manganese (autumn spraying). 4. Metallocene D (3 1/ha) with manganese (autumn spraying). 5. Metallocene D (4 1/ha) with manganese (autumn spraying); two sprayings of Metallocene Universal (1 l/ha) (tillering and earing). 6. Metallocene D (1.0 1/ha) with manganese (autumn application); two sprayings of Metallocene Universal
(1 l/ha) (tillering and earing). 7. Metallocene D (2 1/ha) with manganese (autumn spraying); two sprayings of Metallocene Universal (1 1/ha) (tillering and earing). 8. Metallocene D (3 1/ha) with manganese (autumn spraying); two sprayings of Metallocene Universal (1 l/ha) (tillering and earing). 9. Metallocene D (4 1/ha) with manganese (autumn spraying); two sprayings of Metallocene Universal (1 l/ha) (tillering and earing).

Menallocen D contains $14.2 \%$ of manganese and $5.36 \%$ of total nitrogen. Apart from macroelements, Metallocene Universal contains such microelements as zinc, copper, boron, magnesium, iron, manganese, molybdenum, and cobalt.

The first autumn spraying was carried out during the crop tillering phase. The fertilizer spraying in the spring and summer was performed twice over the vegetation period (during the tillering and earing phases) with a flow rate of process liquid of $200 \mathrm{l} / \mathrm{ha}$. Before the research, the experimental field was fallowed. The soil in the experimental plots is grey forest and middle loamy. The humus content is 3.1-4.0\%, exchangeable soil acidity $=5.4-6.3$. The soil is flush with available forms of phosphorus and potassium.

The winter wheat tillage technology used was standard for the Kama region of the Republic of Tatarstan.

\section{Results and discussion}

The use of fertilizers affected the biometric parameters of winter wheat plants (Table 1).

Table 1. The impact of fertilizing on the biometric parameters of winter wheat plants (before harvesting), 2017-2020

\begin{tabular}{|c|c|c|c|}
\hline $\begin{array}{l}\text { Standard flow rate for } \\
\text { Metallocene } D, 1 / \text { ha }\end{array}$ & $\begin{array}{c}\text { Stalk } \\
\text { length, } \mathrm{cm}\end{array}$ & $\begin{array}{l}\text { Number of seeds in } \\
\text { the ear, pcs }\end{array}$ & $\begin{array}{l}\text { Air dry weight of } \\
\text { the ear, } g\end{array}$ \\
\hline Reference & 74.6 & 39.7 & 1.703 \\
\hline \multicolumn{4}{|c|}{ Metallocene D (autumn) } \\
\hline 1.0 & 75.4 & $41.1^{*}$ & 1.763 \\
\hline 2.0 & 77.7 & $37.8 *$ & 1.843 \\
\hline 3.0 & $69.7 *$ & $37.7 *$ & 1.780 \\
\hline 4.0 & $72.7 *$ & $40.3 *$ & $1.693^{*}$ \\
\hline \multicolumn{4}{|c|}{ Metallocene D (autumn dressing) + Metallocene Universal (spring and summer) } \\
\hline 1.0 & 76.3 & 45.0 & 1.757 \\
\hline 2.0 & 76.7 & $36.1^{*}$ & 1.873 \\
\hline 3.0 & $74.4^{*}$ & $36.7^{*}$ & 2.030 \\
\hline 4.0 & $73.7 *$ & $38.3^{*}$ & 1.583 \\
\hline
\end{tabular}

Note: * - not validated by the reference values at $\mathrm{P}=0.01$.

The assessment results show that the use of Metallocene D at the rate of 1 and 2 1/ha in the autumn only results in the increase of the stalk length while with higher rates ( 3 and 4 1/ha) this value is a bit lower than the reference. The same results were obtained when the autumn dressing was complemented by Metallocene Universal spraying in the spring and summer.

The number of seeds in the ear did not increase except for the plot with the standard flow rate of manganese fertilizer of $1.0 \mathrm{l} / \mathrm{ha}$ (both the autumn 
dressing and the subsequent application of Metallocene Universal).

The positive impact of the methods under analysis (except the plots with the flow rate of Metallocene D of $4 \mathrm{l} / \mathrm{ha}$ ) was the most significant in terms of the dry weight of the ear. The highest parameters were observed when using Metallocene D (3 1/ha) + Metallocene Universal.

The results of the winter wheat yield assessment are presented in Table 2.

For the autumn fertilization with Metallocene D only, the best yield was obtained when using the flow rate of $11 /$ ha. As we can see from the table, the use of this rate increased the yield by $0.67 \mathrm{t} / \mathrm{ha}$, and the surplus of 2020 was especially significant due to the moisture. Similar results were obtained when adding Metallocene Universal: the best yield was observed when the autumn spraying of manganese fertilizers was performed at the rates of 1 and 2 1/ha.

Over the three years, the highest maximum yield (3.45 t/ha) was obtained when applying Metallocene D in the autumn at the rate of 1 1/ha and then complementing it with two sprayings of Metallocene Universal.

Foliage spraying affected the sowing properties of the new yield seeds (Table 3 ).

Table 2. The yield of Kazanskaya 560 winter wheat when fertilized with Metallocene, $t / h a, 2017-2020$

\begin{tabular}{|c|c|c|c|c|c|}
\hline \multirow{2}{*}{$\begin{array}{c}\text { Standard flow rate } \\
\text { for Metallocene } D \text {, } \\
\text { I/ha }\end{array}$} & \multicolumn{3}{|c|}{ Yield, t/ha } & \multirow{2}{*}{$\begin{array}{c}\text { Average for } 2 \\
\text { years }\end{array}$} & \multirow{2}{*}{$\begin{array}{c}\text { Surplus against } \\
\text { the reference, } \\
\text { t/ha }\end{array}$} \\
\hline & 2018 & 2019 & 2020 & & \\
\hline Reference & 1.66 & 2.05 & 3.34 & 2.35 & \\
\hline \multicolumn{6}{|c|}{ Metallocene D (autumn) } \\
\hline 1.0 & 2.02 & 2.87 & 4.16 & 3.02 & 0.67 \\
\hline 2.0 & 1.18 & 2.66 & 4.07 & 2.64 & 0.29 \\
\hline 3.0 & 1.19 & 2.57 & 3.89 & 2.55 & 0.20 \\
\hline 4.0 & 1.47 & 2.70 & 4.08 & 2.75 & 0.40 \\
\hline \multicolumn{6}{|c|}{ Metallocene D (autumn dressing) + Metallocene Universal (spring and summer) } \\
\hline 1.0 & 2.72 & 3.08 & 4.30 & 3.37 & 1.02 \\
\hline 2.0 & 2.81 & 3.12 & 4.41 & 3.45 & 1.10 \\
\hline 3.0 & 1.75 & 2.66 & 3.94 & 2.78 & 0.43 \\
\hline 4.0 & 1.85 & 2.73 & 3.86 & 2.81 & 0.46 \\
\hline $\mathrm{LSD}_{05}$ & 0.07 & 0.09 & 0.12 & & \\
\hline
\end{tabular}

Table 3. The impact of fertilizing on the sowing properties of the winter wheat seeds, 2017-2020

\begin{tabular}{|c|c|c|c|}
\hline $\begin{array}{l}\text { Standard flow rate for } \\
\text { Metallocene } \mathrm{D}, \mathrm{l} / \mathrm{ha}\end{array}$ & $\begin{array}{c}\text { Laboratory } \\
\text { germination, \% }\end{array}$ & $\begin{array}{c}\text { The number of primordial } \\
\text { roots, pcs/seed }\end{array}$ & $\begin{array}{l}\text { The maximum length of } \\
\text { primordial roots, } \mathrm{cm}\end{array}$ \\
\hline Reference & 94.0 & 3.5 & 15.4 \\
\hline \multicolumn{4}{|c|}{ Metallocene D (autumn) } \\
\hline $1.0 \mathrm{l} / \mathrm{ha}$ & 98.0 & $3.7 *$ & $15.8 *$ \\
\hline $2.0 \mathrm{l} / \mathrm{ha}$ & 96.0 & $3.2 *$ & $15.6^{*}$ \\
\hline $3.0 \mathrm{l} / \mathrm{ha}$ & 100 & $3.8^{*}$ & $15.0^{*}$ \\
\hline $4.0 \mathrm{l} / \mathrm{ha}$ & 96.0 & $3.6^{*}$ & 16.9 \\
\hline \multicolumn{4}{|c|}{ Metallocene D (autumn dressing) + Metallocene Universal (spring and summer) } \\
\hline $1.0 \mathrm{l} / \mathrm{ha}$ & 99.0 & $3.5^{*}$ & 17.0 \\
\hline $2.0 \mathrm{l} / \mathrm{ha}$ & 96.0 & $4.4^{*}$ & 16.9 \\
\hline $3.0 \mathrm{l} / \mathrm{ha}$ & 96.0 & $3.9^{*}$ & 16.7 \\
\hline $4.0 \mathrm{l} / \mathrm{ha}$ & 100 & $3.8^{*}$ & 17.8 \\
\hline
\end{tabular}

Note: $*-$ not validated by the reference values at $\mathrm{P}=0.01$.

The assessment results show that the use of all foliage fertilizer spraying options result in the increase in laboratory germination indicators of the new yield seeds. For some of the samples, it was $100 \%$ (the autumn dressing of Metallocene D at 3 1/ha and Metallocene D at $41 /$ ha + Metallocene Universal). At the same time, the increase in the number of primordial roots that appear when seeds germinate was not confirmed for the experimental samples when they were compared to the reference. The autumn application of manganese fertilizers and the two sprayings of Metallocene Universal resulted in the increased maximum length of primordial roots. This is important because primordial roots play a significant role in the formation of the winter wheat yield if droughts occur. 
Phytopathogen infection rates are also key quality indicators for crop seeds. Seeds accumulate root rot germs. In Tatarstan, the seeds of winter wheat are often infected with fusarium blight, helminthosporium, and Alternaria diseases. The study of the impacts foliage fertilizer spraying has on the pathogen infection rates of the seeds is of high practical importance, especially for organic farming. Thus, we performed phytoaudit to assess the impacts the methods under analysis have on the phytosanitary conditions of the winter wheat seeds (Table 4).

Table 4. The impact of fertilizing on the phytosanitary properties (pathogen infection rates) of winter wheat seeds, \%, 2017-2020

\begin{tabular}{|c|c|c|c|}
\hline $\begin{array}{c}\text { Standard flow rate for } \\
\text { Metallocene D, l/ha }\end{array}$ & Fusarium blight & Alternaria & Helminthosporium \\
\hline Reference & 2 & 47 & 12 \\
\hline \multicolumn{4}{|c|}{ Metallocene D (autumn) } \\
\hline 1.0 & 2 & 39 & 6 \\
\hline 2.0 & 0 & 41 & 2 \\
\hline 3.0 & 0 & 48 & 4 \\
\hline 4.0 & 4 & 46 & 0 \\
\hline Metallocene D (autumn dressing) + Metallocene Universal (spring and summer) \\
\hline 1.0 & 0 & 38 & 0 \\
\hline 2.0 & 0 & 44 & 0 \\
\hline 3.0 & 0 & 42 & 0 \\
\hline 4.0 & 0 & 45 & 2 \\
\hline
\end{tabular}

The analysis shows that the autumn dressing of Metallocene D results in a significant (3-6 times depending on the fertilizer flow rate) reduction in helminthosporium rates in seeds. As for the Alternaria, no significant effects were observed.

The double dressing during the spring and summer period following the autumn dressing helped to suppress the most dangerous infections, such as the fusarium blight and the Helmintosporium disease, in the new seeds almost completely. However, the positive effect for the Alternaria fungus was insignificant.

\section{Conclusion}

Based on the research conducted, we established that the autumn dressing of the manganese-containing Metallocene D has a positive effect on the biometric parameters and the accumulation of the dry biomass of winter wheat. When the autumn application of Metallocene D is complemented by the spring and summer spraying Metallocene Universal during the tillering and earing phases, the positive effects fertilizers have on plant growth is amplified. The autumn dressing of manganese-containing Metallocene $\mathrm{D}$ alone or complemented by the double spraying of Metallocene Universal in the spring and summer resulted in a significant increase in crop output.

When Metallocene D was only applied in the autumn, the highest yield was observed at the fertilizer flow rate of $11 /$ ha (the surplus against the reference is $28.5 \%)$. However, the highest yield of winter wheat (3.45 t/ha, which is $46 \%$ above the reference) was obtained by the dressing of Metallocene $\mathrm{D}$ at a rate of $21 /$ ha in the autumn, and the spraying of Metallocene Universal done twice during the spring and summer period.

Foliage fertilizer spraying improved the laboratory germination of seeds and reduced the root rot agent infection rates. We must note that we did not use any chemical fungicides in our experiments. Therefore, the reduction of seed infection rates due to the application of Metallocene fertilizers may be beneficial when growing winter wheat with the minimum use of pesticides.

\section{Recommendations}

To increase the winter wheat yield and seed quality, we recommend using a three-stage dressing with liquid fertilizers: Metallocene D (1 1/ha) in the autumn and Metallocene Universal twice over the spring and summer period.

\section{References}

1. A.A. Powell, Françoise \& França-Neto Corbineau et al., Seed Sci. and Technol., 33 (2005)

2. M. Nasehzadeh, R.H. Ellis, Annals of Botany, 120, 3 (2017)

3. H.M. Barber, M. Lukac, J. Simmonds, M.A. Semenov, M.J. Gooding, Front. in Plant Sci., 8, 51 (2017)

4. R.E. Naylor, Annals of Applied Biology, 123 (1993)

5. M.G. Akhmetov, I.D. Fadeeva, R.S. Shakirov, R.S. Tagirov (Foliant, Kazan, 2008) 
6. S. Fursov, Agricult. Busin.: econ., manag., 05 (2018)

7. I.D. Kotlyarov, The econ. of Russ. agricult., 2 (2018)

8. I.A. Lebedovsky, Sci. J. of KubSAU, 82, 8 (2012)

9. N.F. Klimashevskaya, M.V. Maksimenko, Modern probl. of sci. and ed., 6 (2012)

10. M.Sh. Tagirov, R.S. Shakirov, R.M. Sabirova, Achievem. of Sci. and Technol. of AIC, 29, 10 (2015)

11. E. Epstein, A.J. Bloom, Sinauer Associates (Sunderland, MA, 2005)

12. D.K. Tripathi, Sh. Singh, S. Singh, S. Mishra, D. Chauhan, N. Dubey, Acta Physiol. Plantar., 37 (2015)

13. E.V. Provalova, V.G. Polovinkin (MT-Tipografia LLC, Ulyanovsk, 2010)

14. S.I. Kambulov et al., Agroengineering in the improvement of energy efficiency of the agricultural sector (2012)
15. R.A. Afanasyev, A.S. Samotoenko, V.V. Galitsky, Fertility, 4 (2010)

16. T.A. Soroka, V.B. Shchukin, V.V. Karakulev, Bull. of Orenburg State Agrar. Univ., 3, 33 (2012)

17. A.Ya. Ksenz, S.I. Kambulov, E.B. Dyomina, Don agrar. Sci. bull., 4, 36 (2016)

18. V.V. Koshelyaev, L.V. Karpova, Volga Reg. Farml., 4, 33 (2014)

19. L.V. Karpova, A.V. Strogonova, Volga Reg. Farml., 4, 53 (2019)

20. R.L. Mann, P.S. Kettlewell, P. Jenkinson, Plant Pathol., 53 (2004)

21. D.R. Graham, M.J. Webb, Soil Science Society of America Inc., Madison, Wisconsin, USA (1991)

22. R. Reuveni, M. Reuveni, Foliar-fertilizer therapy - a concept in integrated pest management, Crop Protect., 17, 111-118 (1998)

23. K. Simoglou, C. Dordas, Crop Protect., 25 (2006) 